\title{
MEDIUM CHAIN AND LONG CHAIN ALKANES HYDROXYLASE- PRODUCING WHOLE CELL BIOCATALYST FROM MARINE BACTERIA
}

\author{
Ahmad Thontowi, Elvi Yetti, Yopi \\ Laboratory of Biocatalyst and Fermentation, Research Center for Biotechnology, Indonesian Institute of \\ Sciences (LIPI), Jalan Raya Bogor Km. 46, Cibinong 16911, Indonesia
}

\begin{abstract}
Alkanes are major component of crude oil that could be hydrolyzed by the enzyme of alkane hydroxylase. The are three types of alkane hydroxylase based on the chain length of alkane such as short-chain length/SCL $\left(\mathrm{C}_{2}-\mathrm{C}_{4}\right)$, medium-chain length/MCL $\left(\mathrm{C}_{5}-\mathrm{C}_{17}\right)$, and long-chain length/LCL $\left(\mathrm{C}>{ }_{18}\right)$. The aims of this study were to characterize and identify alkanes-degrading bacteria from these bacteria. The 30 strains from marine were grown on MCL (Pentane- $\mathrm{C}_{5} \mathrm{H}_{12}$, Decane- $\mathrm{C}_{10} \mathrm{H}_{22}$, and Pentadecane- $\mathrm{C}_{15} \mathrm{H}_{32}$ ) and LCL (n-Paraffin- $\mathrm{C}_{12} \mathrm{H}_{19} \mathrm{C}_{17}$ and branch of Pristane$\mathrm{C}_{19} \mathrm{H}_{40}$ ). The study showed twenty-nine isolates have the ability to degrade alkanes compounds, whereas 14 isolates have grown ability on MCL and LCL medium, 11 isolates have the ability to grow on MCL and n-LCL, 3 isolates have the ability only to grow on MCL medium and 1 isolate has the ability only grow on n-LCL medium. The growth test result indicated that 29 isolates have medium-chain alkane monooxygenase and long-chain alkane hydroxylase. Based on 16S rDNA gene analysis, we obtained twenty nine of oil- degrading bacteria, namely $\alpha$-proteobacteria (57 $\%), \gamma$-proteobacteria (30\%), Flavobacteria (7\%), Bacilli (3\%) and Propionibacteriales $(3 \%)$. $\gamma$-Proteobacteria and $\alpha$-proteobacteria which seems to play an important role in the alkane biodegradation.
\end{abstract}

Keywords: alkane, alkane hydroxylase, marine, bacteria

*Corresponding author: Ahmad Thontowi

Cibinong Science Center, Jl. Raya Bogor Km. 46, Cibinong 16911, Indonesia

Tel. +62-21-8754587, Fax. +62-21-87754588

E-mail. ahmad.thontowi@lipi.go.id

\section{Introduction}

Crude oil constituents are classified into four fractions: saturates hydrocarbons (alkane), aromatics hydrocarbons, resins and asphaltenes (Harayama et al., 1999). Alkanes constitute about $20-50 \%$ of crude oil, depending on the source of the oil (Head et al., 2006). As alkanes are non-polar molecules with very low chemical activity, their utilization by microorganisms faces significant challenges, due to several factors, such as low water solubility, high degree accumulation in cell membranes, and higher activation energies (Labinger \& Bercaw, 2002). At least sixty genera of aerobic bacteria, and five genera of anaerobic bacteria (Liu et al., 2014), such as Pseudomonas (Zhang et al., 2011), Acinetobacter (Maeng et al., 1996), Rhodococcus (Van Hamme \& Ward, 2001) and Dietzia (Wang et al., 2011), have been reported capable to degrade aliphatic hydrocarbons.

$n$-alkanes hydrolysis could be initiated by enzymes that belong to different families, among others the microorganisms capable to degrade of short-chain alkanes $(\mathrm{SCL})\left(\mathrm{C}_{2}-\mathrm{C}_{4}\right)$ have enzymes related to methane monooxygenase (van Beilen JB \& Funhoff EG. 2005). The microorganisms degrading medium-chain length alkanes (MCL) $\left(\mathrm{C}_{5}-\mathrm{C}_{17}\right)$ generally contain $\mathrm{P} 450 \mathrm{~s}$ and non-heme iron monooxygenase, such as AlkB (Rojo, 2009). Furthermore, the alkane hydroxylases of longchain length (LCL) alkanes $\left(>\mathrm{C}_{18}\right)$ are unrelated to the above alkane hydroxylases as characterized recently. One such hydroxylase, AlmA, is an LCalkane monooxygenase from Acinetobacter. A second hydroxylase is LadA, which is a thermophilic soluble LC-alkane monooxygenase from Geobacillus (Cerniglia, 1992; Throne-Holst et al., 2006).

Isolation of alkane-degrading bacteria, the biochemical and genetic analyses of alkane degradation from sub-tropical marine have been reported (Cerniglia, 1992; Throne-Holst et al., 2006), and there is few report of alkane degrading bacteria from tropical marine (Widada et al., 2002; Harwati et al., 2007). However, information of alkane hydroxylase from these isolates not yet been reported. Oil-degrading bacteria from Jakarta bay have been isolated (Yopi et al., 2006), but their ability on degrading the alkane have not been analyzed. It is important to analyze the potency of those isolates and the existing of alkane hydroxylase gene. 
The aims of this study were to characterize and identify alkanes-degrading bacteria from the marine area in Jakarta Bay, Indonesia. In this study, we report 29 bacterial strains which were capable of growing on medium with medium chain and long chain alkane that indicated they have various alkanes hydroxylase.

\section{Materials and Methods}

\section{Bacteria strain and media}

Thirteen bacterial isolates from marine used in this study are the collection of Research Center for Biotechnology, Indonesian Institute of Sciences (LIPI). The bacteria were grown in ONR7 medium (Dyksterhouse et al., 1995) including alkane as substrate. The composition of ONR7 medium are $22.79 \mathrm{~g} \mathrm{NaCl}, 11.18 \mathrm{~g}$ $\mathrm{MgCl}_{2} \cdot 6 \mathrm{H}_{2} \mathrm{O}, \quad 3.98 \mathrm{~g} \quad \mathrm{Na}_{2} \mathrm{SO}_{4}, \quad 1.46 \mathrm{~g}$ $\mathrm{CaCl}_{2} \cdot 2 \mathrm{H}_{2} \mathrm{O}, 1.3 \mathrm{~g} \mathrm{3}$-[N-tris (hydroxymethyl) methylamino]-2-hydroxypropane sulfonic acid (TAPSO), $0.72 \mathrm{~g} \mathrm{KCl}, 0.27 \mathrm{~g} \mathrm{NH}_{4} \mathrm{Cl}, 89 \mathrm{mg}$ $\mathrm{Na}_{2} \mathrm{HPO}_{4} \cdot 7 \mathrm{H}_{2} \mathrm{O}, 83 \mathrm{mg} \mathrm{NaBr}, 31 \mathrm{mg} \mathrm{NaHCO}$, $27 \mathrm{mg} \mathrm{H}_{3} \mathrm{BO}_{3}, 24 \mathrm{mg} \mathrm{SrCl} \cdot 6 \mathrm{H}_{2} \mathrm{O}, 2.6 \mathrm{mg} \mathrm{NaF}$, and $2.0 \mathrm{mg} \mathrm{FeCl} \cdot 4 \mathrm{H}_{2} \mathrm{O}$ for $1 \mathrm{~L}$ solution.

\section{Growth Test on Alkanes}

The isolates were analyzed for their ability to utilize a variety of alkanes compound with an addition of $50 \mathrm{ppm}$ of n-Pentane $\left(\mathrm{C}_{5} \mathrm{H}_{12}\right)$, Decane $\left(\mathrm{C}_{10} \mathrm{H}_{22}\right)$, Pentadecane $\left(\mathrm{C}_{15} \mathrm{H}_{32}\right)$ as substrate-classified this medium into MCL. Paraffin and Pristane $\left(\mathrm{C}_{19} \mathrm{H}_{40}\right)$ in the medium were used as a substrate for LCL. The cultures were incubated at $30^{\circ} \mathrm{C}, 1400 \mathrm{rpm}$ for seven days at on Deepwell Maximizer (Bioshaker MBR022UP) and triplicates for all treatments. The cell density of isolates was measured at $\lambda=600 \mathrm{~nm}$.

\section{S rRNA gene analysis}

Genomic DNA was isolated using InstaGene (BioRad). DNA of the partial 16S rDNA gene was amplified by using 9F primer (5AGRGTTTGATCMTGGCTCAG-3) and 1492R primer (5-TACGGYTACCTTGTTAYGACTT3) (Cayalca et al., 1999). PCR cycle condition are $95^{\circ} \mathrm{C}, 2 \mathrm{~min}(1$ cycle $) ; 95^{\circ} \mathrm{C}, 30$ seconds, $65^{\circ} \mathrm{C}, 1 \mathrm{~min}, 72^{\circ} \mathrm{C}, 2 \mathrm{~min}(10$ cycles $) ; 95^{\circ} \mathrm{C}, 30$ sec, $55^{\circ} \mathrm{C}, 1 \mathrm{~min}, 72^{\circ} \mathrm{C}, 2 \mathrm{~min}$ (30 cycles); and $72^{\circ} \mathrm{C}, 2$ min ( 1 cycle). The PCR products were analyzed by electrophoresis on $0.8 \%$ agarose gel. The PCR product was also purified using AGENCOURT ${ }^{\circledR}$ CLEANSEQ ${ }^{\circledR}$ Dye-Terminator Removal (Beckman Coulter-USA) according to the manufacturer recommendations for sequence analysis. Purified DNA was sequenced using DNA sequencer ABI 310 (Pharmacia). The obtained nucleotide sequences were analyzed with BioEdit. Either BLSTX (Altschul et al., 1997) was used for homology searching. Multiple alignments and phylogenetic tree of 16S rDNA gene were produced by CLUSTAL X
(Higgins \& Sharp, 1988) and the phylogenetic tree was visualized by the NJ plot program (Thompson et al., 1994) and Mega 3.1 ABI sequencer software (Kumar et al., 2004).

\section{Results}

\section{Cell Growth in Alkanes}

Biodegradation of n-alkanes compound was investigated in presence of medium- and longchain n-alkanes. The growth test was performed in ONR7 medium in the presence of $50 \mathrm{ppm}$ mixed alkanes (Pentane, Decane, Pentadecane, Paraffin, and Pristane), given as the only carbon and energy source and tested in 7 days. Pentane, decane, and pentadecane are representative of MCL alkane, while paraffin and pristane are LCL alkane. An increase of biomass accumulation was observed by spectrophotometric analysis at OD600.

The 30 strains were tested for their cell growth in ONR7 media containing MCL alkanes $\left(\mathrm{C}_{5}-\mathrm{C}_{15}\right)$, i.e pentane, decane, and pentadecane. Based on the growth of cells, these isolates could use MCL alkane compounds, except isolates number 5 (Fig.1).
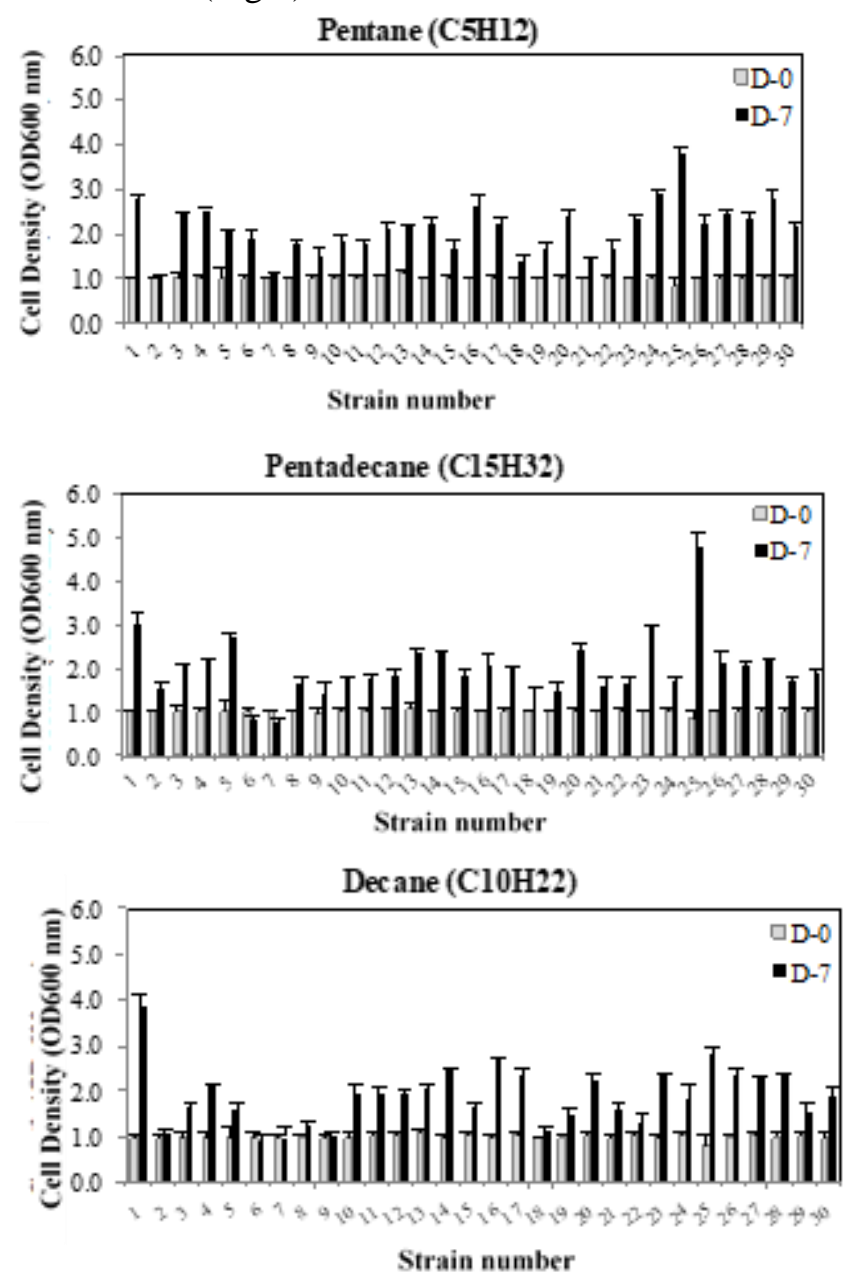

Strain number 

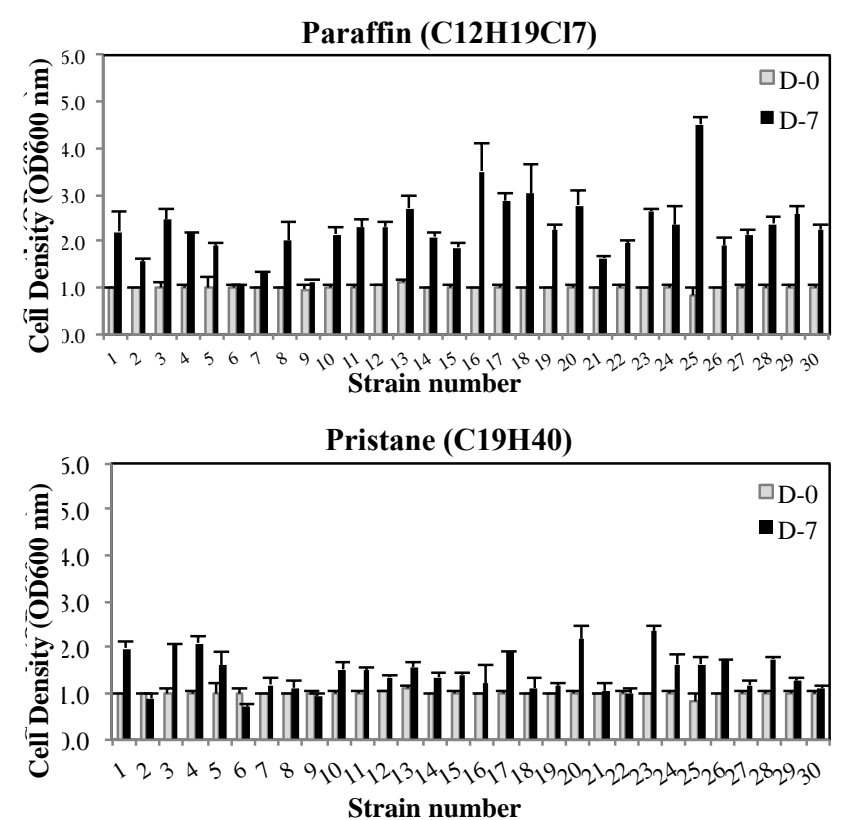

Fig 1. The cell growth of the isolates in ASW medium containing $50 \mathrm{mM}$ alkanes at $30^{\circ} \mathrm{C}$ during 7 days incubation. D-0: day $0(\square)$; D7:day 7

Growth test of 30 strain bacteria were conducted in ONR7 media containing LCL alkanes $\left(>\mathrm{C}^{12}\right)$, ie paraffin and pristane. Paraffin represents a compound having a linear chain alkane. These compounds have a range of chain length $\mathrm{C}^{10}-\mathrm{C}^{40}$. It is expected to be easier to screen bacteria with the ability of the alkane degradation (Throne-Holst et al., 2006). While pristane represent compounds which have branched-chain alkanes.

\section{Alkane Hydroxylase Biocatalyst Diversity}

$n$-alkanes hydrolysis could be initiated by enzymes that belong to different families. Based on a capability of alkanes consumption, 14 could grow on MCL and LCL medium, 11 could grow in MCL and n-LCL, 3 isolates could only grow MCL medium and 1 isolate could only grow in nLCL medium (Fig. 3). The growth test result has indicated that 29 isolates produce medium-chain alkane monooxygenase and long-chain alkane hydroxylase.

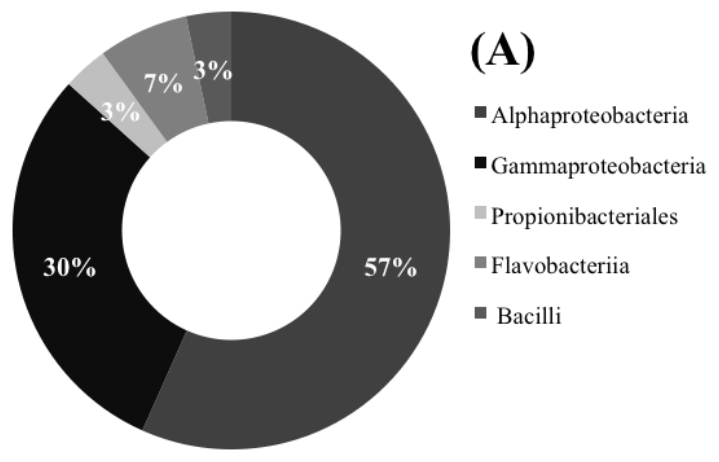

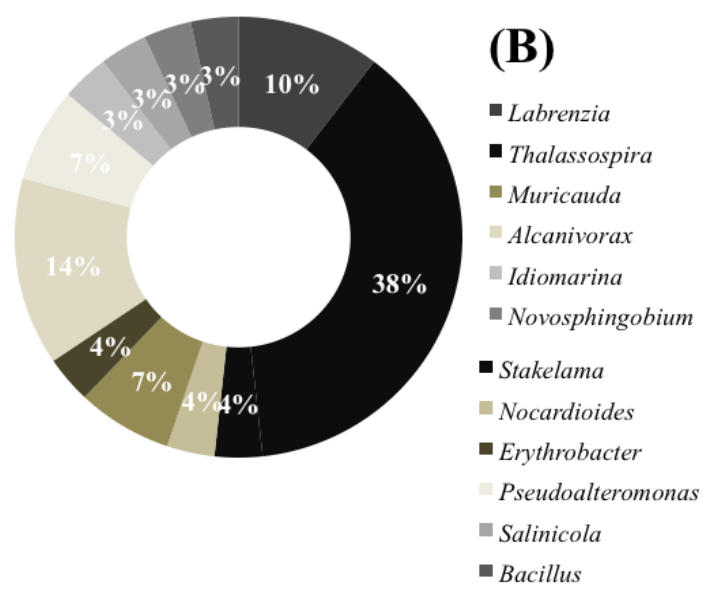

Fig. 2. Biodiversity of alkanes degrading bacteria based on (A) family and (B) species

Table 1. Bacteria identities were used in this study

\begin{tabular}{|c|c|c|c|c|}
\hline No. & $\begin{array}{l}\text { Private } \\
\text { Culture } \\
\text { Number }\end{array}$ & $\begin{array}{c}\text { Most similar 16S rDNA } \\
\text { sequence }\end{array}$ & Reference & $\%$ \\
\hline 1 & LBF-1-0001 & $\begin{array}{l}\text { Labrenzia aggregata IAM } \\
12614\end{array}$ & NR115659 & 99 \\
\hline 2 & LBF-1-0002 & Stakelama pacifica JLT832 & NR116368 & 99 \\
\hline 3 & LBF-1-0003 & $\begin{array}{l}\text { Thalassospira permensis } \\
\text { SMB34 }\end{array}$ & NR116841 & 99 \\
\hline 4 & LBF-1-0004 & $\begin{array}{l}\text { Nocardioides perillae I10A- } \\
01402\end{array}$ & NR109521 & 99 \\
\hline 5 & LBF-1-0005 & Muricauda aquimarina SW-63 & NR042909 & 99 \\
\hline 6 & LBF-1-0006 & $\begin{array}{l}\text { Erythrobacter nanhaisediminis } \\
\text { T30 }\end{array}$ & NR116764 & 99 \\
\hline 7 & LBF-1-0008 & Alcanivorax dieselolei $\mathrm{B} 5$ & NR074734 & 99 \\
\hline 8 & LBF-1-0009 & Muricauda aquimarina SW-63 & 2909 & 100 \\
\hline 9 & LBF-1-0010 & $\begin{array}{l}\text { Pseudoalteromonas } \\
\text { shioyasakiensis SE3 }\end{array}$ & NR125458 & 99 \\
\hline 10 & LBF-1-0011 & $\begin{array}{l}\text { Pseudoalterom } \\
\text { shioyasakiensi }\end{array}$ & NR125458 & 99 \\
\hline 11 & LBF-1-0012 & Stakelama pacifica JLT832 & NR116368 & 99 \\
\hline 12 & LBF-1-0013 & Stakelama pacifica JLT832 & NR116368 & 99 \\
\hline 13 & LBF-1-0014 & Alcanivorax dieselolei $\mathrm{B} 5$ & NR074734 & 99 \\
\hline 14 & LBF-1-0015 & $\begin{array}{l}\text { Labrenzia aggregata IAM } \\
12614\end{array}$ & NR115659 & 99 \\
\hline 15 & LBF-1-0016 & $\begin{array}{l}\text { Labrenzia aggregata IAM } \\
12614\end{array}$ & NR115659 & 99 \\
\hline 16 & LBF-1-0017 & Alcanivorax xenomutans JC109 & NR133958 & 99 \\
\hline 17 & LBF-1-0018 & pacifica JLT832 & NR116368 & 99 \\
\hline 18 & LBF-1-( & ifica JLT832 & 368 & 99 \\
\hline 19 & LBF-1-0020 & Idiomarina baltica $\mathrm{OS} 145$ & NR027560 & 99 \\
\hline 20 & LBF-1-0021 & Stakelama pacifica JLT832 & NR116368 & 99 \\
\hline 21 & LBF-1-0022 & Alcanivorax xenomutans JC109 & NR133958 & 99 \\
\hline 22 & LBF-1-0023 & pacifica JLT832 & NR116368 & 99 \\
\hline 23 & LBF-1-0024 & Stakelama pacifica JLT832 & NR116368 & 99 \\
\hline 24 & LBF-1-0025 & Salinicola peritrichatus DY22 & NR109731 & 97 \\
\hline 25 & LBF-1-0026 & Stakelama pacifica JLT832 & NR116368 & 99 \\
\hline 26 & LBF-1-0027 & Stakelama pacifica JLT832 & NR116368 & 99 \\
\hline 27 & LBF-1-0028 & $\begin{array}{l}\text { Novosphingobium resinovorum } \\
\text { NCIMB } 8767\end{array}$ & NR044045 & 99 \\
\hline 28 & LBF-1-0029 & Stakelama pacifica JLT832 & NR116368 & 99 \\
\hline 29 & LBF-1-0030 & $\begin{array}{l}\text { Bacillus subtilis subsp. subtilis } \\
\text { OS-44.a }\end{array}$ & NR114997 & 99 \\
\hline
\end{tabular}


Table 2. Strains producing medium chain alkane hydroxylase and long chain alkane hydroxylase

\begin{tabular}{|c|c|c|c|}
\hline $\begin{array}{l}\text { Type of } \\
\text { alkane } \\
\text { hydroxy } \\
\text { lase }\end{array}$ & Strain & $\begin{array}{c}\text { Number } \\
\text { of } C\end{array}$ & References \\
\hline \multirow[t]{5}{*}{ MCL } & Thauera butanivorans & $\mathrm{C}_{2}-\mathrm{C}_{9}$ & $\begin{array}{c}\text { (Johnson \& Harayama, } \\
\text { 2006) }\end{array}$ \\
\hline & $\begin{array}{l}\text { Pseudomonas oleovorans } \\
\text { GPo1 }\end{array}$ & $\mathrm{C}_{5}-\mathrm{C}_{12}$ & (Funhoff et al. 2006) \\
\hline & $\begin{array}{l}\text { Mycobacterium sp. HXN- } \\
1500\end{array}$ & $\mathrm{C}_{6}-\mathrm{C}_{11}$ & Maier et al. (2001) \\
\hline & Acinetobacter sp. EB104 & $\mathrm{C}_{5}$ & Zhou et al. (2011) \\
\hline & $\begin{array}{l}\text { Novosphingobium } \\
\text { aromaticivorans DSM } 12444\end{array}$ & $\mathrm{C}_{3}-\mathrm{C}_{8}$ & Kotani et al. (2003) \\
\hline \multirow[t]{32}{*}{ LCL } & Gordonia sp. strain TY-5 & $\mathrm{C}_{13}-\mathrm{C}_{22}$ & $\begin{array}{l}\text { Kotani et al. (2007); Li et } \\
\text { al. (2008) }\end{array}$ \\
\hline & $\begin{array}{l}\text { Geobacillus } \\
\text { thermodenitrificans NG80-2 }\end{array}$ & $\mathrm{C}_{15}-\mathrm{C}_{36}$ & Bihari et al. (2007) \\
\hline & $\begin{array}{l}\text { Acinetobacter haemolyti- cus } \\
\text { strain AR-46 }\end{array}$ & $\mathrm{C}_{16}-\mathrm{C}_{35}$ & Lal \& Khanna (1996) \\
\hline & $\begin{array}{l}\text { Acinetobacter sp. strain DSM } \\
17874\end{array}$ & $\mathrm{C}_{10}-\mathrm{C}_{40}$ & Throne et al. (2006) \\
\hline & Acinetobacter sp. DSM17874 & $\mathrm{C}_{10}-\mathrm{C}_{40}$ & Throne et al. (2006 \\
\hline & Alcaligenes odorans P20 & $-\mathrm{C}_{33}$ & Schneiker et al. (2006) \\
\hline & $\begin{array}{l}\text { Alcanivorax borkumensis } \\
\text { AP1 }\end{array}$ & $\mathrm{C}_{10}-\mathrm{C}_{20}$ & $\begin{array}{c}\text { van Beilen \& Funhoff } \\
\text { (2005) }\end{array}$ \\
\hline & $\begin{array}{l}\text { Alcanivorax borkumensis } \\
\text { SK2 }\end{array}$ & $\mathrm{C}_{8}-\mathrm{C}_{32}$ & Radwan et al. (1996) \\
\hline & $\begin{array}{l}\text { Arthrobacter nicotianae } \\
\text { KCC B35 }\end{array}$ & $\mathrm{C}_{10}-\mathrm{C}_{40}$ & Chaerun et al. (2004) \\
\hline & $\begin{array}{l}\text { Bacillus thuringiensis/cereus } \\
\mathrm{A} 2\end{array}$ & $\mathrm{C}_{6}-\mathrm{C}_{28}$ & Yan (2006) \\
\hline & Brachybacterium sp. & $\mathrm{C}_{10}-\mathrm{C}_{20}$ & Wang et al. (2016) \\
\hline & Burkholderia cepacia RR10 & $\mathrm{C}_{12}-\mathrm{C}_{34}$ & Yuste et al (2000) \\
\hline & $\begin{array}{l}\text { Desulfatibacillum } \\
\text { aliphaticivorans } \mathrm{CV} 2803\end{array}$ & $\mathrm{C}_{13}-\mathrm{C}_{18}$ & $\begin{array}{c}\text { Cravo-Lauren et al. } \\
(2000)\end{array}$ \\
\hline & Dietzia cinnamea $\mathrm{P} 4$ & $\mathrm{C}_{11}-\mathrm{C}_{24}$ & $\begin{array}{l}\text { von der Weid et al. } \\
(2006)\end{array}$ \\
\hline & Dietzia psychralcaliphila & $\mathrm{C}_{13}-\mathrm{C}_{24}$ & Yumoto et al. (2002) \\
\hline & $\begin{array}{l}\text { Geobacillus } \\
\text { thermodenitrificans NG80-2 }\end{array}$ & $\mathrm{C}_{15}-\mathrm{C}_{36}$ & Wang et al. (2006) \\
\hline & Gordonia sp. TY-5 & $\begin{array}{l}\mathrm{C}_{3}, \mathrm{C}_{13^{-}} \\
\mathrm{C}_{22}\end{array}$ & Kotani et al. (2003) \\
\hline & $\begin{array}{l}\text { Marinobacter } \\
\text { hydrocarbonoclasticus } 617\end{array}$ & $\mathrm{C}_{16}-\mathrm{C}_{30}$ & Doumennq et al. (2001) \\
\hline & $\begin{array}{l}\text { Marinobacter } \text { sp. BC36, } \\
\mathrm{BC} 38, \text { and } \mathrm{BC} 42\end{array}$ & $\mathrm{C}_{18}$ & Bonin et al. (2004) \\
\hline & Mycobacterium sp. HXN 600 & $\mathrm{C}_{6}-\mathrm{C}_{24}$ & van Beilen et al. (2002) \\
\hline & $\begin{array}{l}\text { Paracoccus } \\
\text { sereniphilus/marcusii } \mathrm{A} 7\end{array}$ & $\mathrm{C}_{6}-\mathrm{C}_{28}$ & Chaerun et al. (2004) \\
\hline & $\begin{array}{l}\text { Paracoccus sp. strains Ophe1 } \\
\text { and Sphe1 }\end{array}$ & $\mathrm{C}_{10}-\mathrm{C}_{28}$ & Zhang et al. (2003) \\
\hline & $\begin{array}{l}\text { Planococcus alkanoclasticus } \\
\text { MAE2 }\end{array}$ & $\mathrm{C}_{11}-\mathrm{C}_{33}$ & Enegelhardt et al. (2001) \\
\hline & $\begin{array}{l}\text { Pseudomonas aeruginosa } \\
\text { PAO1 }\end{array}$ & $\mathrm{C}_{12} \mathrm{C}_{24}$ & Smits et al. (2002) \\
\hline & $\begin{array}{l}\text { Pseudomonas aeruginosa } \\
\text { strains A1, A3, A4, A5, A6 }\end{array}$ & $\mathrm{C}_{6}-\mathrm{C}_{28}$ & Chaerun et al. (2004) \\
\hline & $\begin{array}{l}\text { Pseudomonas fluorescens } \\
\text { CHA0 }\end{array}$ & $\mathrm{C}_{12}-\mathrm{C}_{32}$ & Smits et al. (2002) \\
\hline & $\begin{array}{l}\text { seudomonas sp. PUP6 } \\
\end{array}$ & $\mathrm{C}_{12}-\mathrm{C}_{28}$ & Naik \& Sakthivel (2006) \\
\hline & $\begin{array}{l}\text { Rhodococcus sp. strains T12 } \\
\text { and TMP2 }\end{array}$ & $\mathrm{C}_{9}-\mathrm{C}_{22}$ & Kunihiro et al. (2005) \\
\hline & Thalassolituus oleivorans & $\mathrm{C}_{7}-\mathrm{C}_{20}$ & Yakimov et al. (2004) \\
\hline & Thermus sp. C2 & $\mathrm{C}_{9}-\mathrm{C}_{39}$ & Hao et al. (2004) \\
\hline & Weeksella sp. RR7 & $\mathrm{C}_{12}-\mathrm{C}_{34}$ & Yuste et al. (2004) \\
\hline & Xylella fastidiosa RR15 & $\mathrm{C}_{14}-\mathrm{C}_{34}$ & Yuste et al. (2004) \\
\hline
\end{tabular}

\section{Discussion}

In general, bacterial isolates tested were able to grow better in pentane than in the decane and pentadecane. This is understandable because the compound has a number of $\mathrm{C}$ atoms pentane less than others. So that these bacteria could utilize pentane as $\mathrm{C}$ source and energy better than the decane and pentadecane.

Meanwhile, isolate number 25 had the highest cell growth after incubated in ONR7 media containing pentadecane. This isolate has good cell growth in the all medium-chain alkane compounds. We hypothesized that isolate have an alkane hydroxylase which was capable to utilize the medium chain alkane compounds.

The highest bacterial growth in media containing decane is achieved by isolate number 25. These isolates identified as Salinicola peritrichatus (Table 1). S. peritrichatus is a Gram-negative bacteria, aerobic and rod-shaped bacterium. This strain was isolated from sediment in Pacific Ocean (Huo et al., 2013) and the mangrove ecosystem in India (Raiu et al., 2015). This genus has never been reported capable of utilizing pentane/alkanes for his growth and also for naphthalene-polycyclic aromatic hydrocarbons (Anan'ina et al., 2007).

The highest bacterial growth in media containing decane is achieved by isolate number 1. This isolate was identified as Labrenzia aggregata (Table 1). L. aggregata is a Gramnegative bacteria, aerobic and motile (Wang et al., 2016). This genus has been isolated from the hipersaline environment (Biebl et al., 2007; Bibi et al., 2014; Bacosa et al., 2015). Genus of Labrenzia was able to grow in an oil contaminated environment as reported by several investigators (Overholt et al., 2013; Bacosa et al., 2015; Militon et al., 2015).

Based on the growth of cells, in general, bacteria were grown better in paraffin than pristane (Fig. 1). This phenomenon occurs because pristane is branched-chain alkane which is more difficult to degrade. Thus the bacteria take longer to degrade than when grown in a paraffin which is a straight chain alkane.

One method for microbial identification is a molecular analysis by using some genes of bacteria. Currently, part of DNA that is often used for the taxonomy analysis of bacteria is $16 \mathrm{~S}$ rDNA gene (Bottger, 1989; Pace et al., 1997). This gene has unique properties in a biosynthesis system and also this gene is widely distributed in the cell. Technically, this gene is stored well on a broad ranges phylogeny data and the availability of complete data in the GenBank make PCR amplification of this gene become easier.

The composition of marine bacteria is not different from that of the composition of marine bacteria in the North Sea and Road Bay, Antartica (Harayama et al., 1999; Ouatrini et al., 2008). Beside these two classes, there are also families Actinobacteria, Bacillales, and Flavobacteria. The different results are reported from the diversity of oil-degrading bacteria in marine waters Semarang, Central Java, Indonesia. The reported $\alpha$-proteobacteria was even more isolated from this area (Harwati et al., 2007). These results indicate a wide range of oildegrading bacteria in the regions of the waters of Indonesia, making it an attractive study for further exploration. Meanwhile, actinomycetes class dominate and hold the key bioremediation alkane compounds in the Mediterranean Sea (Chen et al., 2010). Oil- degrading bacteria diversity in several different locations is thought to occur because of differences in location and 
environmental conditions $\left(\mathrm{O}_{2}\right.$, electron receiver, temperature, redox potential, salinity, and $\mathrm{pH}$ )
(Harayama et al., 1999).

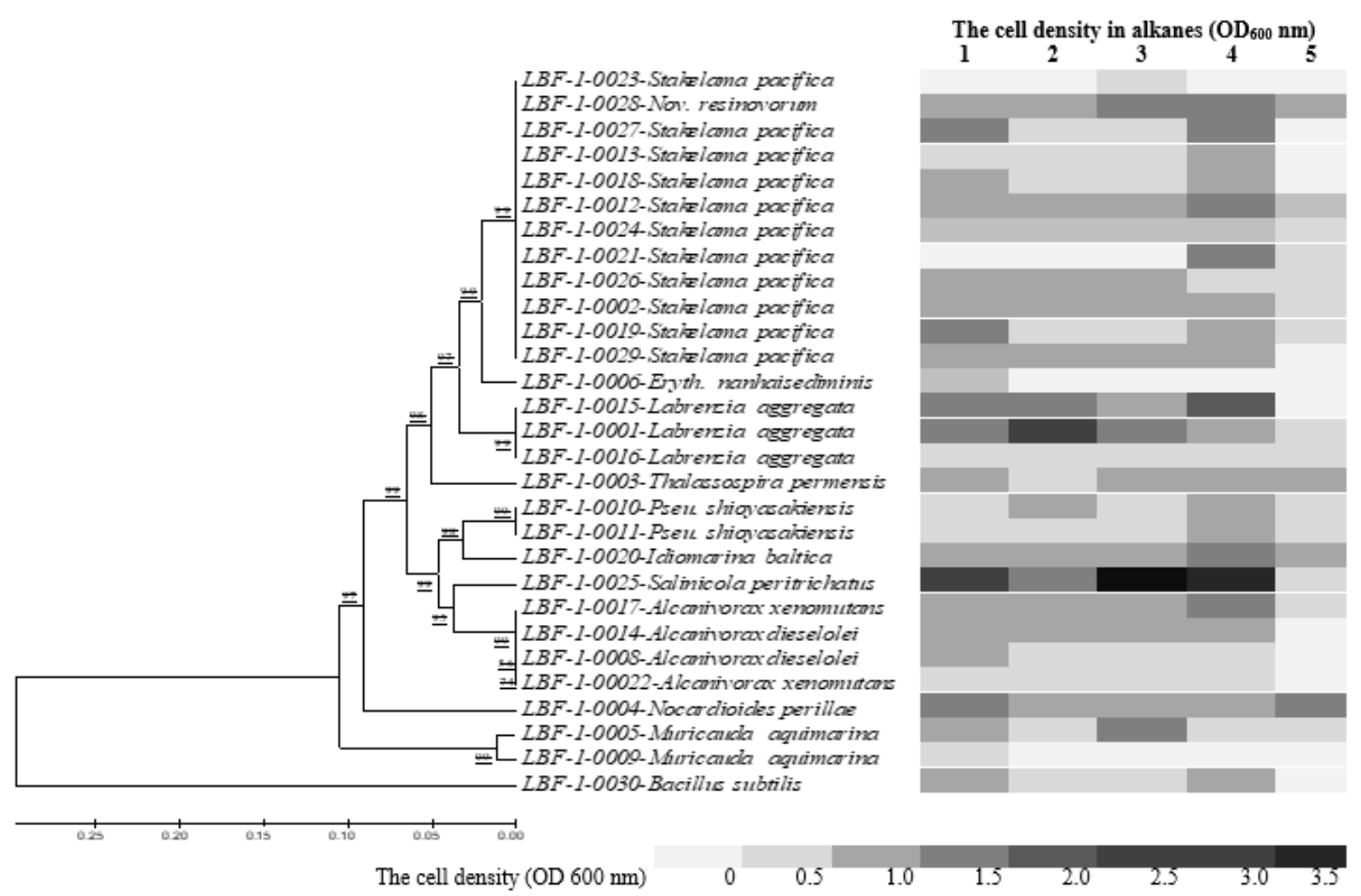

Fig 3. Biodiversity of alkane degrading bacteria and their phenotypic activity for alkanes degradation. 1: $\mathrm{n}$ Pentane $\left(\mathrm{C}_{5} \mathrm{H}_{12}\right)$, 2: Decane $\left(\mathrm{C}_{10} \mathrm{H}_{22}\right)$, 3: Pentadecane $\left(\mathrm{C}_{15} \mathrm{H}_{32}\right)$, 4: Paraffin, and 5: Pristane $\left(\mathrm{C}_{19} \mathrm{H}_{40}\right)$.

Based on the genus information of alkanes degrader, we identified 12 species of bacteria. Genus of Stakelama dominates alkanedegrading bacteria. Stakelama is a Gram reaction-negative, weakly motile, non-sporeforming, rod-shaped, and aerobic bacterium (Thawng et al., 2012). This genus was isolated at Pacific ocean (Thawng et al., 2012), and tidal flat sediment (Kostka et al., 2011). One paper reported that isolate isolated from Gulf Mexico seawater could be degrade oil (van Beilen \& Funhoff, 2005).

One isolate of alkanes degrader has a difference of more than $3 \%$ of identity value or less than $97 \%$ with gene bank database, LBF-10025 isolate (Table 1). This isolate suspected to be new species (Yurui et al., 2013). However, this proposal must be verified using several methods of identification of bacteria, such as morphology and biochemistry. Unfortunately, these tests were not done in this study. Bacterial identification is only evaluated by analyzing the $16 \mathrm{~S}$ rDNA gene. We obtained bacteria which have MCL and LCL alkane hydroxylase from Indonesia sea water area. This result indicated that the biodiversity of alkane hydroxylase very diverse in Indonesia. As a comparison of the results was shown several types of microorganisms and their ability to produce MCL and LCL (Table 2). Genus of Pseudomonas, Bacillus, and Alcanivorax were reported to have MCL alkane hydroxylase (Fox et al., 1992; van Beilen \& Funhoff, 2005). Also for LCL alkane hydroxylase from Geobacillus thermodenitrificans NG80-2, utilizes a terminal oxidation pathway for the conversion of longchain n-alkanes (from $\mathrm{C}_{15}$ to at least $\mathrm{C}_{36}$ ) to corresponding primary alcohols (Halsey et al., 2006). Further study of alkane hydroxylase from Indonesia marine bacteria will be carried out more detail.

\section{Acknowledgements}

We would like to thank for DIPA Tematik of Research Center for Biotechnology LIPI 2016 and Project of SATREPS Development of Internationally Standardized Microbial Resources Center As A Core of Biological Resources Center to Promote Life Science Research and Biotechnology 2011-2016. 


\section{References}

Altschul, S. F., T. L. Madden, A. A. Schäffer, J. Zhang, Z. Zhang, W. Miller, \& D. J. Lipman. (1997). Gapped BLAST and PSI-BLAST: a New Generation of Protein Database Search Programs. Nucleic Acids Research, 25, 3389-3402.

Anan'ina, L.N., Plotnikova, E.G., Gavrish, E.I., Demakov, V.A., \& Evtushenko, L.I. (2007). Salinicola socius gen. nov., sp. nov., a moderately halophilic bacterium from a naphthalene-utilizing microbial association. Mikrobiologiia, 76(3), 36976.

Bibi, F., Jeong, J.H., Chung, E.J., Jeon, C.O., \& Chung, Y.R. (2014). Labrenzia suaedae sp. nov., a marine bacterium isolated from a halophyte, and emended description of the genus Labrenzia. International Journal of Systematic and Evolutionary Microbiology, 64, 1116-1122. doi: http://dx.doi.org/10.1099/ijs.0.052860-0.

Biebl, H., Pukall, R., Lunsdorf, H., Schulz, S., Allgaier, M., Tindall, B.J., \& Wagner-Dobler, I. (2007). Description of Labrenzia alexandrii gen. nov., sp. nov., a novel alphaproteobacterium containing bacteriochlorophyll a, and a proposal for reclassification of Stappia aggregata as Labrenzia aggregata comb. nov., of Stappia marina as Labrenzia marina comb. nov. and of Stappia alba as Labrenzia alba comb. nov., and emended descriptions of the genera Pannonibacter, Stappia and Roseibium, and of the species Roseibium denhamense and Roseibium hamelinense. International Journal of Systematic and Evolutionary Microbiology, 57(Pt 5), 10951097.

Bihari, Z., Pettko-Szandtner, A., Csanadi, G., Balazs, M., Bar- tos, P., \& Kesseru, P., et al., (2007). Isolation and characterization of a novel n-alkanedegrading strain, Acinetobacter haemolyticus AR46. Z. Naturforsch C, 62, 285-295.

Bonin, P., Cravo-Laureau, C., Michotey, V., \& Hirschler-Rea, A. (2004). The anaerobic hydrocarbon biodegrading bacteria: an overview. Ophelia, 58, 243-254.

Bottger, E.C. (1989). Rapid determination of bacterial ribosomal RNA sequences by direct sequencing of enzymatically amplified DNA, FEMS Microbiology Letters, 65, 171-176.

Cavalca, L., A. Hartmann, N. Rouard, \& G., Soulas. (1999). Diversity of tfdC Gene: Distribution and Polymorphism Among 2,4-DichloRophenoxyacetic Acid Degrading Soil Bacteria. FEMS Microbiology Ecology, 29, 45-58.

Cerniglia, C.E. (1992). Biodegradation of polycyclic aromatic hydrocarbons. Biodegradation, 3:351368.

Chaerun, S.K, Tazaki, K., Asada, R., Kogure, K. (2004). Bioremediation of coastal areas 5 years after the Nakhodka oil spill in the Sea of Japan: isolation and characterization of hydrocarbondegrading bacteria. Environmental International, $30,911-922$.

Chen, C., Zheng, Q., Wang, Y.N., Yan, X.J., Hao, L.K., Du, X., \& Jiao, N. (2010). Stakelama pacifica gen. nov., sp. nov., a new member of the family Sphingomonadaceae isolated from the Pacific Ocean. International Journal of
Systematic and Evolutionary Microbiology, 60(Pt 12), 2857-61. doi: 10.1099/ijs.0.018945-0.

Cravo-Laureau, C., Matheron, R, Cayol, J.L., Joulian, C., \& Hirschler-Rea, A. (2004). Desulfatibacillum aliphaticivorans gen. nov., sp nov., an n-alkane- and n-alkene-degrading, sulfate-reducing bacterium. International Journal of Systematic and Evolutionary Microbiology, $54: 77-83$

Doumenq, P., Aries, E., Asia, L., Acquaviva, M., Artaud, J., Gilewicz, M., Mille, G., \& Bertrand, J.C. (2001). Influence of $n$-alkanes and petroleum on fatty acid composition of a hydrocarbonoclastic bacterium: Marinobacter hydrocarbonoclasticus strain 617. Chemosphere, 44, 519-528

Dyksterhouse, S. E., J. P. Gray, R. P. Herwig, J. C. Lara, \& J. T. Staley. (1995). Cycloclasticus pugetii gen. nov., sp. nov., an Aromatic Hydrocarbon-Degrading Bacterium from Marine Sediments. International Journal of Systematic and Evolutionary Microbiology, 45(1), 116-123.

Engelhardt, M.A., Daly, K., Swannell, R.P., \& Head, I.M. (2001). Isolation and characterization of a novel hydrocarbon-degrading, gram-positive bacterium, isolated from intertidal beach sediment, and description of Planococcus alkanoclasticus sp. nov. Journal of Applied Microbiology, 90, 237-247.

Fox, G.E, Wisotzkey, J.D., \& Jurtshuk, P.J.R. (1992). How close is close: 16s rRNA sequence identity may not be sufficient to guarantee species identity. International Journal of Systematic and Evolutionary Microbiology, 90(2), 166-170.

Funhoff, E.G., Bauer, U., Garcia- Rubio, I., Witholt, B., \& Van Beilen, J.B. (2006). CYP153A6, a soluble P450 oxygenase catalyzing terminalalkane hydroxylation. Journal of Bacteriology, 188, 5220-5227.

Halsey, K. H., Sayavedra-Soto, L.A., Bottomley, P. J., \& Arp, D.J. (2006). Site-directed amino acid substitutions in the hydroxylase alpha sub-unit of butane monooxygenase from Pseudomonas butanovora: implications for substrates knocking at the gate. Journal of Bacteriology, 188, 49624969.

Hao, R., Lu, A., \& Wang, G. (2004). Crude-oildegrading thermophilic bacterium isolated from an oil field. Canadian Journal of Microbiology, 50, $175-182$

Harayama, S., Kishira, H., Kasai, Y. \& Shutsubo, K. (1999). Petroleum biodegradation in marine environments. Journal Molecular Microbiol and Biotechnol, 1, 63-70.

Harwati, U.T., Kasai, Y., Kodama, Y., Susilaningsih, D., \& Watanabe, K. (2007). Characterization of diverse hydrocarbon-degrading bacteria isolated from Indonesia Seawater. Microbes and Environments, 22(4), 1-4

Head, I.M., Jones, D.M., \& Roling, W.F. (2006). Marine microorganisms make a meal of oil. Nature Reviews Microbiology, 4, 173-182.

Higgins, D.G. \& P.M., Sharp. (1988). CLUSTAL: a Package for Performing Multiple Sequence Alignment on a Microcomputer. Gene, 73, 237244.

H.P. Bacosa, Z., Liu, \& D.L., Erdner. (2015). Natural Sunlight Shapes Crude Oil-Degrading Bacterial Communities in Northern Gulf of Mexico Surface 
Waters. Front Microbiology, 6, 1325. doi: 10.3389/fmicb.2015.01325.

Huo, Y.Y., Meng, F.X., Xu, L., Wang, C.S., 7 Xu, X.W. (2013). Salinicola peritrichatus sp. nov., isolated from deep-sea sediment. Antonie Van Leeuwenhoek. 104(1), 55-62. doi: 10.1007/s10482-013-9925-1.

Johnson, E. L., \& Hyman, M. R. (2006). Propane and n-butane oxidation by Pseudomonas putida GPo1. Applied Environmental Microbiology, 72, 950952.

Kostka, J.E., O. Prakash, W. A. Overholt, S. J. Green, G. Freyer, A. Canion, J. Delgardio, N. Norton, T. C. Hazen, \& M. Huettel. (2011). Hydrocarbon Degrading Bacteria and the Bacterial Community Response in Gulf of Mexico Beach Sands Impacted by the Deepwater Horizon Oil Spill. Applied Environmental Microbiology, 77(22), 7962-7974.

Kotani, T., Yamamoto, T., Yuri- moto, H., Sakai, Y., $\&$ Kato, N. (2003). Propane monooxygenase and NAD+ -dependent secondary alcohol dehydrogenase in propane metabolism by Gordonia sp. strain TY-5. Journal of Bacteriology. 185, 7120-7128.

Kotani, T., Yurimoto, H., Kato, N., \& Sakai, Y. (2007). Novel acetone metabolism in a propaneutilizing bacterium, Gordonia sp. strain TY-5. Journal of Bacteriology, 189, 886-893.

Kumar, S., K. Tamura, \& M. Nei. (2004). MEGA3: Integrated Software for Molecular Evolutionary Genetics Analysis and Sequence Alignment. Briefings Bioinformatics, 5, 150-163.

Kunihiro, N., Haruki, M., Takano, K., Morikawa, M., \& Kanaya, S. (2005). Isolation and characterization of Rhodococcus sp. strains TMP2 and T12 that degrade 2,6,10,14tetramethylpentadecane (pris- tane) at moderately low temperatures. Journal of Biotechnology, $115,129-136$.

Labinger, J.A., \& Bercaw, J.E. (2002). Understanding and exploiting C-H bond activation. Nature, 417 , $507-514$.

Lal, B., \& Khanna, S. (1996). Degradation of crude oil by Acinetobacter calcoaceticus and Alcaligenes odorans. Journal of Applied Bacteriology, 81, 355-362

Li, L., Liu, X., Yang, W., Xu, F., Wang, W., Feng, L., et al., (2008). Crystal structure of long-chain alkane monooxygenase ( $\operatorname{LadA})$ in complex with coenzyme FMN: unveiling the long-chain alkane hydroxylase. Journal Molecular Biology, 376, $453-465$.

Liu, H., Xu, J., Liang, R., \& Liu, J. Characterization of the Medium- and Long-Chain n- Alkanes Degrading Pseudomonas aeruginosa Strain SJTD-1 and Its Alkane Hydroxylase Genes. (2014). PLOS ONE, 9(8), e105506:1-14.

Maeng, J.H., Sakai, Y., Tani, Y., \& Kato, N. (1996). Isolation and characterization of a novel oxygenase that catalyzes the first step of n-alkane oxidation in Acinetobacter sp. strain M-1. Journal of Bacteriology, 178, 3695-3700.

Maier, T., Forster, H. H., Asperger, O., and Hahn, U. (2001). Molecular characterization of the $56-\mathrm{kDa}$ CYP153 from Acinetobacter sp. EB104.
Biochemical and Biophysical Research, 286(3), $652-658$.

Militon C, Jézéquel R, Gilbert F, Corsellis Y, Sylvi L, Cravo-Laureau C, Duran R, Cuny P. (2015). Dynamics of bacterial assemblages and removal of polycyclic aromatic hydrocarbons in oilcontaminated coastal marine sediments subjected to contrasted oxygen regimes. Environmental Science and Pollution Research, 22,15260-15272. doi: http://dx.doi.org/10.1007/s11356-015-4510y.

Naik PR, Sakthivel N. (2006). Functional characterization of a novel hydrocarbonoclastic Pseudomonas sp. strain PUP6 with plant- growthpromoting traits and antifungal potential. Research in Microbiology, 157:538 - 546.

Overholt WA, Green SJ, Marks KP, Venkatraman R, Prakash O, Kostka JE. (2013). Draft genome sequences for oil-degrading bacterial strains from beach sands impacted by the Deepwater Horizon oil spill. Genome An-nouncement, 1(6): e0101513. doi: http://dx.doi.org/10.1128/genomeA.01015-13.

Pace, N. (1997). A molecular view of microbiol diversity and the biosphere. Science, 276, 734740.

Yakimov MM, Giuliano L, Denaro R, Crisafi E, Chernikova TN, Abraham WR, Luensdorf $\mathrm{H}$, Timmis KN, \& Golyshin PN. (2004). Thalassolituus oleivorans gen. nov., sp. nov., a novel marine bacterium that obligately utilizes hydrocarbons. International Journal of Systematic and Evolutionary Microbiology, 54, 141-148.

Quatrini P., Scaglione G., De Pasquale C., Riela S., \& Puglia A. M. (2008), Isolation of Gram-positive nalkane degraders from a hydrocarboncontaminated Mediterranean shoreline. Journal of Applied Microbiology, 104, 251-259.

Radwan SS, Sorkhoh NA, Felzmann H, \& ElDesouky AF. (1996). Uptake and utilization of noctacosane and n-nonacosane by Arthrobacter nicotianae $\mathrm{KCC}$ B35. Journal of Applied Bacteriology, 80, 370-374.

Raju, K., Sekar, J., \& Vaiyapuri, R. P. (2015). Salinicola rhizosphaerae sp. nov., isolated from the rhizosphere of the mangrove Avicennia marina L. International Journal of Systematic and Evolutionary Microbiology, 66(2), 10741079.doi: 10.1099/ijsem.0.000837.

Rojo, F. (2009). Degradation of alkanes by bacteria. Environmental Microbiology, 11, 2477-2490.

Schneiker, S., Santos M.V.A., Bartels, D., Bekel, T., Brecht, M., Buhrmester, J., Chernikova, T.N., Denaro, R., Ferrer, M., Gertler, C., Goesmann, A., Golyshina, O.V., Kaminski, F., Khachane, A.N., Lang, S., Linke, B., McHardy, A.C., Meyer, F., Nechitaylo, T., Puhler, A., Regenhardt, D., Rupp, O., Sabirova, J.S., Selbitschka, W., Yakimov, M.M., Timmis, K.N., Vorholter, F.J., Weidner, S., Kaiser, O., \& Golyshin, P.N. (2006). Genome sequence of the ubiquitous hydrocarbondegrading marine bacterium Alcanivorax borkumensis. Nature Biotechnology, 24, 9971004

Smits, T.H., Balada, S.B., Witholt, B., \& van Beilen, J.B. (2002). Functional analysis of alkane hydroxylases from gram-negative and gram- 
positive bacteria. Journal of Bacteriology, 184, 1733-1742.

Thawng, C.N., Park, S.J., Cha, J.H., \& Cha, C.J. Stakelama sediminis sp. nov., isolated from tidal flat sediment. (2013). International Journal of Systematic and Evolutionary Microbiology, 63(Pt 2), 560-4. doi: 10.1099/ijs.0.039743-0.

Thompson, J. D., D. G. Higgins, \& T. J. Gibson. (1994). CLUSTAL W: Improving the Sensitivity of Progressive Multiple Sequence Alignment through Sequence Weighting, Position-Specific Gap Penaltiesand Weight Matrix Choice. Nucleic Acids Research, 22, 4673-4680.

Throne-Holst, M., Markussen, S., Winnberg, A., Ellingsen, T.E., Kotlar, H.K., \& Zotchev, S.B. (2006). Utilization of n-alkanes by a newly isolated strain of Acinetobacter venetianus: the role of two AlkB- type alkane hydroxylases. Applied Microbiology and Biotechnology, 72, 53-360.

van Beilen, J.B., \& Funhoff, E.G. (2005). Expanding the alkane oxygenase toolbox: new enzymes and applications. Current Opinion in Biotechnology, 16(3), 308-314.

Van Beilen, J.B., Smits, T.H.M., Whyte, L.G, Schorcht, S., Röthlisberger, M., Plaggemeier, T., Engesser, K.H., \& Witholt, B. (2002). Alkane hydroxylase homologues in Gram-positive strains. Environment Microbiology, 4:676-682

Van Hamme, J.D., \& Ward, O.P. (2001). Physical and metabolic interactions of Pseudomonas sp. strain JA5-B45 and Rhodococcus sp. strain F9D79 during growth on crude oil and effect of a chemical surfactant on them. Applied Environmental Microbiology, 67, 4874-4879.

Von der, W.I., Marques, J.M., Cunha, C.D., Lippi, R.K., Dos Santos, S.C., Rosado, A.S., Lins, U., \& Seldin, L. (2006). Identification and biodegradation potential of a novel strain of Dietzia cinnamea isolated from a petroleumcontaminated tropical soil. System Applied Microbiology, 30, 331-339

Wang, L., Tang, Y., Wang, S., Liu, R.L., Liu, M.Z., Zhang, Y., Liang, F.L., Feng, L. (2006). Isolation and characterization of a novel thermophilic Bacillus strain degrading long-chain n-alkanes. Extremophiles, 10(4), 347-56.

Wang, X.B., Chi, C.Q., Nie, Y., Tang, Y.Q., Tan, Y., et al., (2011). Degradation of petroleum hydrocarbons $\left(\mathrm{C}_{6}-\mathrm{C}_{40}\right)$ and crude oil by a novel Dietzia strain. Bioresources Technology, 102, 7755-7761.

Wang, Z., B.J., Eddie, A.P. Malanoski, W.J ., Hervey, I.V., B., Lin, \& S.M.S., Glaven. (2016). Complete genome sequence of Labrenzia sp. strain $\mathrm{CP} 4$, isolated from a self-regenerating biocathode biofilm. Genome Announcement, 4(3), e00354-16. doi: 10.1128/genomeA.00354-16.

Widada, J., Nojiri, H., Kasuga, K., Yoshida, T., Habe, H., \& Omori, T. (2002). Molecular detection and diversity of polycyclic aromatic hydrocarbon- degrading bacteria isolated from geographically diverse sites. Applied Microbiology and Biotechnology, 58, 202-209.

Yakimov, M.M., Giuliano, L., Denaro, R., Crisafi, E., Chernikova, T.N., Abraham, W.R., Luensdorf, H., Timmis, K.N., \& Golyshin, P.N. (2004). Thalassolituus oleivorans gen. nov., sp. nov., a novel marine bacterium that obligately utilizes hydrocarbons. International Journal of Systematic and Evolutionary Microbiology, 54, 141-148.

Yan, P.L. (2006). Alkane-degrading functional bacteria, its cultivation method and application. CN1789408, 2006-06-21, CN20041081505 20041217, CHENGDU BIOLOGY RES INST OF TH $(\mathrm{CN})$.

Yopi, Theresia, U.H., Ahmad Thontowi, \& Dwi Susilaningsih. (2006). Karakterisasi bakteri pendegradasi minyak bumi dari perairan Muara Kamal, Teluk Jakarta. In Prosiding Seminar Nasional Bioteknologi 2006 (pp. 423- 427). November 15-16, 2006. Cibinong. ISBN: 9789799778932.

Yumoto, I., Nakamura, A., Iwata, H., Kojima, K., Kusumoto, K., Nodasaka, Y., \& Matsuyama, H. (2002). Dietzia psychralcaliphila sp. nov., a novel, facultatively psychrophilic alkaliphile that grows on hydrocarbons. International Journal of Systematic and Evolutionary Microbiology, 52, 85-90.

Yurui, Ji., Guannan, Mao, Yingying, Wang, \& Bartlam, M. (2013). Structural insights into diversity and n-alkane biodegradation mechanisms of alkane hydroxylases. Frontiers in Microbiology, 4(58), 1-13.

Yuste, L., Corbella, M.E., Turiegano, M.J., Karlson, U., Puyet, A., \& Rojo, F. (2000). Characterization of bacterial strains able to grow on high molecular mass residues from crude oil processing. FEMS Microbiology and Ecology, 32, 69-75.

Yuste, L., Corbella, M.E., Turiegano, M.J., Karlson, U., Puyet, A., Rojo, F. (2000). Characterization of bacterial strains able to grow on high molecular mass residues from crude oil processing. FEMS Microbiology and Ecology, 32, 69-75.

Zhang, H., Kallimanis, A., Koukkou, A.I., \& Drainas, C. (2004). Isolation and characterization of novel bacteria degrading polycyclic aromatic hydrocarbons from polluted Greek soils. Applied Microbiology and Biotechnology, 65,124-131.

Zhang, Z., Hou, Z., Yang, C., Ma, C., \& Tao, F. (2011). Degradation of $n$-alkanes and polycyclic aromatic hydrocarbons in petroleum by a newly isolated Pseudomonas aeruginosa DQ8. Bioresources Technology, 102, 4111-4116.

Zhou, R., Huang, C., Zhang, A., Bell, S.G., Zhou, W., \& Wong, L.L. (2011). Crystallization and preliminary from Novosphingobium aromaticivorans DSM12444. Acta Crystallographica Section F Structural Biology and Crystallization Communicationa, 67(Pt8), $964-967$. 